\author{
DONALD 1. MACKAY \\ DAVID J.C. FORSYTH \\ $D A V I D M . K E L L Y$
}

\title{
THE DISCUSSION OF PUBLIC WORKS PROGRAMMES, I917-1935: SOME REMARKS ON THE LABOUR MOVEMENT'S CONTRIBUTION
}

One of the by-products of the Keynesian Revolution has been a painstaking search for precursors of Keynes. Diligent academics have compiled an impressive array of "proto-Keynesians", although some have only slender claims to the title. ${ }^{1}$ There has been a preoccupation with those writers whose contributions were exclusively theoretical. 'This bias is surprising in view of the nature of Keynes' own approach which was to progress from policy prescription to theory. ${ }^{2}$ The "proto-Keynesians" in general failed to proceed to Keynesian policy prescriptions, being unable to withstand the attacks of orthodox theorists; yet some commentators, ignorant of theoretical niceties, intuitively arrived at policy programmes which Keynes later endorsed. This latter group placed particular emphasis on public works programmes as a method of combating unemployment. Economists have credited the Liberal Party, J. M. Keynes and H. D. Henderson with being the first, in the inter-war years, to emphasise public works as one solution to the problem of chronic unemployment. Klein, examining Keynes' and Henderson's arguments ${ }^{3}$ in support of the Liberal Party's 929 General Election commitment to a public works programme, ${ }^{4}$ states that "no one was thinking seriously along these lines at the time of the Great Depression." Most other commentators have stressed the original nature of the

${ }^{1}$ Even Keynes was inclined to force the writing of earlier economists into his own mould. Cf. R. F. Harrod, The Life of John Maynard Keynes (195I), p. 460, and Joan Robinson, Economic Philosophy (1962), p. 20.

${ }^{2}$ For example, in collaboration with H. D. Henderson, Keynes, in 1929 supported a policy of public works clearly implying that this would lead to secondary employment (cf. Can Lloyd George Do It? An Examination of the Liberal Pledge). The rigorous formulation of the "multiplier theory" by Kahn (Economic Journal, June 1931) followed two years later.

${ }^{8}$ Can Lloyd George Do It? (The Nation and Athenaeum, 1929).

4 The Liberal programme was outlined in Britain's Industrial Future (1928) and We Can Conquer Unemployment (I929).

5 L. R. Klein, The Keynesian Revolution(1952), p. 13. 
Liberal programme of 1929 , notably Harrod, Macgregor and Dillard. ${ }^{1}$ The purpose of this paper is to indicate the contribution of the Labour movement to the inter-war discussion of public works. It is contended that there has been undue emphasis on the Liberal Party's literature of the 1920s and early 1930s. In fact, the Liberal programme was in many respects similar to that which had been expounded by trade unionists and the Labour Party since 1917. To establish this argument it is necessary, first, to outline the historical background against which the inter-war discussion of public works took place.

The idea that public works may be useful in a depression has a long lineage. Although public works programmes go back at least as far as the Pyramids such programmes, designed to have a bearing on employment, are of relatively recent origin. Four strands can be distinguished in the discussion of public works. First the unemployed are put to work in order to fulfil certain social and moral rather than economic objectives. Secondly, public works can be used in a conscious attempt to raise employment but the argument relates only to the primary effect on employment. Thirdly, public works are advocated with a conscious appreciation of a multiplier effect. Fourthly and finally the idea emerges that such works should be deficit financed rather than financed through increased taxation. ${ }^{2}$

The Poor Law of the igth century was designed to reduce unemployment by increasing its unattractiveness. It was recognised that physical disablement or economic calamity ${ }^{3}$ might result in unemployment and that in these circumstances the repressive spirit of the Poor Law should be modified. However, these exceptions were narrowly interpreted. The fundamental principle underlying the Poor Law was the deterrence of those who might find relief preferable to employment. Thus the able bodied poor were to receive relief only if certain conditions were fulfilled, the most important of these

${ }^{1}$ R. F. Harrod, loc. cit., pp. 345-353 and 392-396. D. H. Macgregor, Economic Thought and Policy (1949), pp. 95-98 and D. Dillard, The Economics of John Maynard Keynes (1948), pp. 309-310.

2 The multiplier principle is merely a statement that in a situation where productive resources are idle an increase in government expenditure will give employment not only to those directly involved but will also have secondary effects. The importance of this is that the Exchequer does not have to carry the cost of the total increase in employment but merely that fraction of employment directly given by government projects. Financing such expenditure by taxation could mean that this increase in government spending might be offset by a decline in private spending. Hence, the principle of deficit financing where the government expenditure is met by printing more money or by borrowing from the public.

${ }^{8}$ Hence the public works instituted during the Irish potato famine and the "Cotton Famine" in Lancashire. 
being the fulfilment of a labour test. Such was the hold of this idea that as late as 1926 the Norwich Guardians paid relief to ablebodied unemployed only if they reported four times a week to a shed three miles outside the city in which they were locked for seven hours!1 The Chamberlain and Fowler circulars of 1886 and 1892 gave official blessing to municipal relief works but as the Poor Law Commissioners of 1909 observed, "there was little or nothing economically to differentiate the work in 1886 from the work provided by the guardians as a condition of relief."' In practice, municipal relief works were criticised because there was no differentiation between applicants, no standard of competence laid down, work done was of little utility and commanded the trade union wages prevailing. The Unemployed Workmen Act of 1905 was intended to apply to those temporarily unemployed - the chronically unemployed were to be catered for by the Poor Law. The Act established Distress Committees comprised of representatives from Local Authorities, Boards of Guardians and charitable organisations and, not unnaturally, retained in an attenuated form the principles which underlaid the work of these bodies. In practice the Act was criticised in much the same way as the work undertaken independently by the municipal authorities. These critics saw public works acting as a "safety net" for those temporarily unemployed. They should, therefore, select only those who where competent, lay down standards of performance and undertake only work which had utility. ${ }^{3}$ But neither those who made provision for relief work nor the critics had any clear concept that such provisions might be used to combat unemployment. Thus Davison argued that where the work had utility "to withdraw these orders from ordinary business tended by so much to create unemployment among the persons ordinarily employed in that line." 4 Beveridge who at certain points seemed to grasp that public works could be used to stabilise employment argued "that a rising demand for labour is no cure for unemployment." 5

Economists since Steuart have recognised the possibility that in the certain circumstances government intervention might be necessary to maintain employment. This idea is common to such traditionally contrasted writers as Say and Hobson. These last both argued that

1 R. C. Davison, The Unemployed (1929), p. 7.

2 Poor Law Commission, 1909, Majority Report, p. 378.

3 See R. C. Davison, op. cit., pp. 23-62, and Lord Beveridge, Unemployment: A Problem of Industry, pp. I 50-197.

R. C. Davison, op. cit., p. I 2.

${ }^{5}$ Beveridge, op. cit., p. 193 . For a glimpse of the idea that public works may be varied contra-cyclically see p. $23 \mathrm{I}$. 
in a depression, savings may not be quickly turned into investment and that the government may usefully mobilise the idle balances by taxing them and spending the money on public works. ${ }^{1}$ Although the analysis is primitive and overlooks the possibilities of a multiplier effect and deficit financing, there is here the suggestion that depression might be cured or averted by public works. Most academic economists writing before 193 I did not reach this level of enlightenment. They tended to regard public works as a palliative, something that alleviated rather than cured unemployment. Thus public works had the limited effect of reducing the "average level of unemployment" by minimising economic dislocation and the deterioration of the labour force that accompany severe depression. The orthodox view was that, in general, public works increased employment in one sector (or time-period) at the cost of creating unemployment pari passu, in the next. "It is, indeed, true that the State is unable by action of the kind contemplated [public works], to increase the demand for labour on the whole on the average of good and bad times together."2 State investment was merely a placebo like shorttime working and emigration of which Pigou concluded "that not even the adoption of all of them together would avail to abolish unemployment."3

In the discussions of economists there was no clear indication that the basis of the multiplier relationship was understood. The exception was Johannsen who had no impact on the "English School" until the latter had painfully "discovered" the principle for themselves. It is in the argument related to the multiplier process that the Labour and Liberal movements made their contribution to the inter-war discussion of public works. At the end of the nineteenth century the "right to work or maintenance" had been a theme of the Social Democratic Federation and the Independent Labour Party. Working class disenchantment with orthodox economics was longstanding. The experience of trade unionists gave the lie to the "Classicial" conception of an economic mechanism automatically restoring fullemployment through the medium of flexible interest rates and money wages. Thus Checkland observes, "Trade unionists in the [eighteen] seventies, like Alexander Macdonald and George Potter, argued [that] the competitive system forced employers into a position in which rational behaviour was impossible." While economists remained preoccupied with distribution and "were mainly concerned with an attempt to revive and perfect the formalism of the older thinking", trade unionists

I J. A. Hobson, The Industrial System (1909), pp. 300-301.

2 A. C. Pigou, Unemployment (1913), p. I72. By a different route Hawtrey arrives at a similar conclusion.

${ }^{3}$ Pigou, op. cit., p. 246. 
"had more or less abandoned political economy at the theoretical level." The exception to this was the Marxists with whom the abandonment of the traditional political economy took a more positive form. They saw crises as the result of the inherent contradictions of the capitalist system. This being so they found no solution in "tinkering" with the existing system but looked to a society in which the collective ownership of the means of production would remove the causes of periodic slumps. Although this paper is mainly concerned with those who, like Keynes, worked within the given capitalist framework this latter Marxist or radically socialist group remained an important element in the labour movement throughout the interwar period. ${ }^{2}$

The dislocation which would arise from demobilisation intensified fears in the labour movement that laissez-faire policies would be inadequate. Thus at the end of the First World War The Prevention of Unemployment After the War (1917) and Labour and the New Social Order (I918) emphasised the State's duty to offset fluctuations in private demand by public works programmes. In 19 9 trade unionists, building on this foundation, were able to present a more detailed argument which contained striking "Keynesian" elements. On February $27^{\text {th }}$ the Government, concerned with the problems of "Reconstruction" and industrial unrest, convened an Industrial Conference representing both sides of industry. The Conference appointed a Provisional Joint Committee, with equal representation of employers and trade unionists ${ }^{3}$ which reported to a reconvened Industrial Conference on April 4th, 1919.4 This report contains memoranda submitted by the trade unions. It is evident from the first Memorandum that the "Keynesian" elements in the White Paper derive from the trade union proposals on employment policy. ${ }^{5}$

The trade unions attribute unemployment to the failure of consumption demand. Thus "a very large body of wage earners have received a rate of wages limiting their power of consumption to such an extent as seriously to limit the effective demand for all the essentials of life, and as a consequence unemployment has been created by

1 S. G. Checkland, The Rise of Industrial Socicty in England, 181 5-188 5 (1964), Pp. 424-5, 428 and 430 .

${ }^{2}$ See, for example, John Strachey, The Theory and Practice of Socialism (1936).

${ }^{3}$ Each side had thirty-one representatives. The Chairman and Secretary were appointed by the Government. Amongst the trade union representatives were Arthur Henderson, J. N. Clynes and G. D. H. Cole.

4 Cmd. sor, Report of Provisional Joint Committee, April 4, I919 (1920).

5 "On the causes of and the remedies for labour unrest", App. I. 
under consumption."1 A number of ways in which the Government might increase aggregate demand are suggested. The most important of these is the proposed public works programme. "In order to provide against the fluctuating demand for labour... the Government should undertake the definite duty of stimulating the demand for labour in bad times by postponing contracts of a non-urgent character until it is necessary to promote a demand for labour owing to falling trade,"2 and should allocate "all Government contracts in such a way as to steady the volume of employment." In addition to an expanded housing programme, "The demand for labour would also be increased by State development of new industries such as Afforestation, Reclamation of Waste Lands, Development of Inland Waterways, and in agricultural districts the development of light railways and/or road transport. These are some of the measures which ... might be adopted as a means of permanently increasing the demand for labour." 4 The unions, suspicious of the ability of a private enterprise system to maintain employment regret the resale to private firms of requisitioned shipyards and factories; "the factories, as well as the shipyards, might have been turned to the task of useful peace-time production, and might have been made a powerful factor for the prevention of unemployment both during the period of dislocation and permanently." 5 What is significant in this is the emphasis on public works as an aspect of anti-cyclical policy and the refusal to acknowledge the argument that the Government is powerless to do anything more than shift the burden of unemployment from one sector to another.

The second category of policy proposals arise from the belief that consumption demand must be given a direct stimulus. The trade unionists begin with the very crude under-consumptionist argument that a wage increase will have the direct effect of increasing employment, ${ }^{\mathbf{6}}$ but proceed to demand a comprehensive system of what are now termed "built-in stabilisers". Hence, legal wage minima should be established for all workers, sickness benefits and old age pensions increased and a comprehensive system of unemployment benefits (with a supplementary allowance for dependent children) introduced. Taken together these measures would raise the "floor" of effective demand and so tend to "permanently increase the demand for labour"'.

${ }^{1}$ Cmd. sor, App. r, p.v.

2 Ibid., p. IO, para 3.

3 Ibid., App. I, p. ix.

4 Ibid., p. I I, para 5.

${ }^{5}$ Cmd. sor, App. I, p. iv.

Ibid., App. I, p. viii.

${ }^{7}$ Cmd. 501 , p. II, para 5. 
It is further suggested that the distribution of income is an important factor in determining the level of aggregate demand and thus the level of employment. "We are of the opinion that the unequal distribution of wealth which prior to the war kept the purchasing power of the majority of the wage earners at a low level constituted a primary cause of unemployment."1 A number of recommendations for reducing income differentials are put forward. Of these the most important is the "graduated levy on capital from which property up to $f \mathrm{r}, 000$ would be exempt". 2

These then are the policy proposals. They are based on no theoretical argument and are limited to domestic policy. Even within this limited ambit monetary policy is neglected and there is no detailed discussion of how the Government's programme is to be financed. Despite these weaknesses the measures suggested contained many of the more important elements of the prescriptions which were to emerge from the General Theory. The economic proposals, however, met with no positive response. The Government was not favourably disposed towards the unions ${ }^{3}$ and had convened the Industrial Conference in an attempt to allay industrial unrest. It was the immediate symptoms of that unrest and the need to evolve machinery to limit it which exercised minds not the more fundamental problem of employment policy. When discussed the policy recommendations were treated with some scepticism. Lloyd George, anticipating the trade unions, argued that unemployment and other benefits, "always cripple[s] the energies of the State in some other direction" and that "it is no use the State undertaking work merely in order to create work. That is the road to national bankruptcy..."4 And Sir Robert Horne (then Minister of Labour) believed that State attempts to guarantee employment could only end in "disaster" and that "government action always does tend ... to weaken the ordinary enterprise of the country." 5

Government neglect of their recommendations did not deter the trade unionists. Throughout the next decade, together with certain members of the Labour Party, they re-iterated and refined the ideas first expressed as a coherent economic policy in the White Paper. They rejected the view that the Government's role "in the prevention

1 Ibid., App. I, p. $\nabla$.

2 Ibid., App. I, p. viii.

${ }^{3}$ H. Pelling, A History of British Trade Unionism(1963), pp. I6o-I62.

4 The Times, 28 Feb. I919.

5 Hansard, i9 Nov. 1919, pp. 975-6. Horne is nevertheless able to approve the Government's housing scheme. This speech is also an interesting example of another confusion between the relative roles of supply and demand, a confusion for which Horne is subsequently taken to task (see Pp. 975-6 and p. 104I). 
and relief of unemployment... is to enforce the utmost application of economy." It was pointed out "that the surest way of increasing the ultimate bill which must be met is to attempt any retrenchment of expenditure for productive purposes; ${ }^{2}$ that "short-time and reduced earnings in one industry immediately react upon others, because the reduced purchasing power of the workers directly affected lessens the demand for all other kinds of commodities and services; and so causes an everwidening circle of workers to become unemployed or under-employed." 3 The adverse multiplier effect results from a failure of demand. "Goods are produced to satisfy an effective demand for them, but where no such demand exists or can be created, no production is undertaken. The lack of effective demand is in fact the ultimate cause of the limited output with which we are at present compelled to be satisfied. But this lack is itself due... to lack of power to purchase in the hands of those who desire to do so ... We travel then, in a circle, as vicious as any in the whole of economic life, in which poverty is the creator of yet further poverty." "At the present time we need more expenditure of the right kind, i.e. expenditure on socially valuable services which will stimulate normal production."

So a number of publications by the labour movement had anticipated the Liberal programme before it was launched by Lloyd George in The Nation in I924. ${ }^{6}$ By 1929 he had completed his volte-face; "we are ready with schemes of work ... work of a kind which is not merely useful in itself but essential to the well-being of the nation. The work put in hand will reduce the terrible figures of the workless ... and will, when completed, enrich the nation and equip it for competing successfully with all its rivals in the business of the world." While the Liberal literature contained more advanced ideas on the financing of State schemes their concept of the multiplier was less well developed. Thus the increased income of those employed on public works "will be reflected at once in a corresponding increase in expenditure on food, clothing .... As a result a stimulus will be given to the whole of the industry and commerce of the country reflected in turn in

1 T.U.C. and Labour Party, Unemployment Relief (1922), p. 2.

2 Unemployment: A Labour Policy (Report of the Joint Committee on Unemployment Appointed by the Parliamentary Committee of the Trades Union Congress and the Labour Party Executive), January 192 I, p. 32.

${ }^{3}$ Ibid. p. 8.

4 The Waste of Capitalism (Labour Joint Publication Dept. 1924), p. I 10.

5 Unemployment: A Labour Policy, p. 32.

6 The Nation, 12 April 1924.

'Lloyd George's address to Liberal candidates I March 1929. Quoted in Can Lloyd George Do It? 
increased employment." The Liberals had grasped the idea that the stock of capital available was not fixed and that State investment could be financed by borrowing without diminishing private investment. This then is the beginning of the fourth strand in the discussion of public works programmes, that such programmes should be deficit financed. It is, however, no more than a beginning. Lloyd George's programme obtained much of its authority from the approval given to it by Henderson \& Keynes in Can Lloyd George Do It? But, the theory of deficit finance was not seriously thought out and the implications of the argument not fully appreciated. That this is so emerges clearly from Henderson's later writings. In 1936 in an address to the Marshall Society at Cambridge he disagreed "fundamentally" with the General Theory and in 1944 argued that a deliberate policy of deficit finance "As a remedy for unemployment ... is fundamentally inappropriate." 2

The Liberal Party must be credited with achieving this insight into the financing of State schemes. But a full appreciation of budgetary policy required the enlightenment of a general theory of income determination. In other respects the Liberal programme of 1929 was essentially the same as that programme earlier advocated by the Labour movement. This being so it is difficult to explain first, the much greater prominence given to the Liberal proposals, and secondly the Labour Party's failure to implement a more comprehensive system of public works as Minority Government from $1929-3 \mathrm{I}$.

The attention which has been paid to the Liberal programme derives, in part, from its more effective propaganda. ${ }^{3}$ But, more important, was the Liberal Party's ability, subsequently, to press for more positive action without having to bear responsibility for the implementation of such action, while those in the Labour Government advocating public works were obliged to demonstrate how this programme was to be financed in the context of a crisis which was international as well as domestic. A comprehensive and satisfactory policy required a deeper understanding of budgetary policy (and the principles of deficit finance) and of the implications of the accepted orthodoxies of Free Trade and the Gold Standard, than at that time prevailed. Keynes himself did not modify his argument "that

1 We Can Conquer Unemployment (1929), p. 52. That the idea is confused is shown in Can Lloyd George Do It? where the multiplier process outlined is merely one whose secondary effects are restricted to related sectors (see p. 24).

${ }^{2}$ H. D. Henderson, The Inter-War Years (1955), p. I61 and p. 322.

${ }^{3}$ See G. D. H. Cole, A History of the Labour Party from I914 (1948), p. 218 , and R.

Bassett, Nineteen Thirty-One: Polititical Crisis(1958), p. 37. 
Protection can not ... cure Unemployment"1 until $193 \mathrm{I}^{2}$ and not till 1933 did he develop arguments which could be properly viewed as advocating "deficit finance". ${ }^{3}$ The Labour Cabinet was divided: Snowden remained implacably opposed to any suggestions that the principles enshrined in balanced budget, Free Trade and Gold Standard orthodoxies ${ }^{4}$ should be modified. Divided against itself, receiving conflicting advice ${ }^{5}$ the Cabinet was unable to institute any major new departures in economic policy or withstand the orthodox logic of the May Committee. ${ }^{6}$

The fall of the Labour Government as a result of its inability to meet the economic crisis tended to obscure the views of the more "enlightened" members of the labour movement. As a consequence the "Keynesian" views of this latter group have been neglected and Keynes and the Liberals credited, by most writers with being the first to suggest public works programmes as one solution to the problems of the depression. In fact many of their ideas were anticipated by the debate within the labour movement in the inter-war years a discussion which ranged over many of the aspects of what was later to be termed the "New Economics".?

It is hoped that this article will stimulate more detailed research into this interesting and significant debate.

1 The Nation and the Athenaeum, Nov. 24, 1923.

2 Committee on Finance and Industry, Cmd. 3897 , (1931), Add. I.

8 The Times 13, 14, 15, 16 March 1933. These articles, somewhat expanded, were subsequently reprinted in The Means to Prosperity (1933).

4 The balanced budget orthodoxy was widely accepted within the Labour Party. Thus Dalton's argument that, "it is, of course, an elementary maxim that States should balance their Budgets". Hansard, is Sept. I93 I, p. 786. There were a few notable exceptions. See ibid. McShane, pp. 386-395 and Noel Baker, pp. 764-774.

${ }^{5}$ See A. Bullock, The Life and Times of Ernest Bevin, Vol. I, pp. 436-439.

- Committee on National Expenditure, Cmd. 3920 (I931).

7 See, for example, Ernest Bevin's views on economic policy in A. Bullock, op. cit., pp. 417-447, and Committee on Finance and Industry, pp, 190-210 and 239-24I; Lansbury, My England (1934), Pp. I 40-1 50, and Ethel Mannin, Confessions and Impressions (1930), p. 164, Mosley's arguments for Protection and the stimulation of demand in G. D. H. Cole, loc. cit., pp. 237-245, and Hansard, 8 Sept. 193 1, pp. 72-82. 